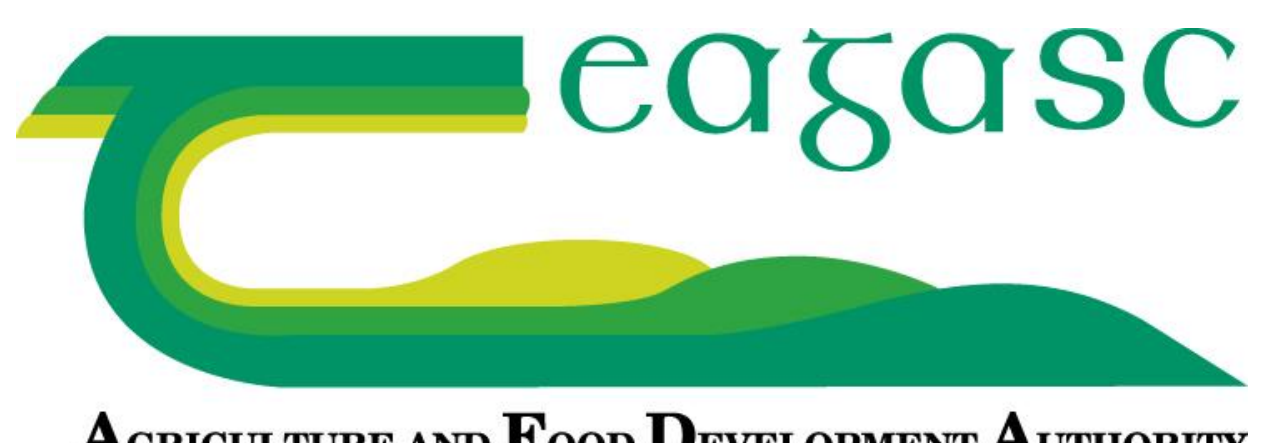

TITLE: Policy drivers of farm succession and inheritance

AUTHORS: Brian Leonard, Anne Kinsella, Cathal O’Donoghue, Maura Farrell, Marie Mahon

This article is provided by the author(s) and Teagasc T-Stór in accordance with publisher policies.

Please cite the published version.

NOTICE: This is the author's version of a work that was accepted for publication in Land Use Policy. Changes resulting from the publishing process, such as peer review, editing, corrections, structural formatting, and other quality control mechanisms may not be reflected in this document. Changes may have been made to this work since it was submitted for publication. A definitive version was subsequently published in, Land Use Policy, 2017, 61, 147-159, DOI: 10.1016/j.landusepol.2016.09.006

This item is made available to you under the Creative Commons Attribution-Non commercial-No Derivatives 3.0 License. 


\title{
Drivers of Farm Succession and Inheritance
}

\begin{abstract}
Farm succession and inheritance is increasingly considered a complex phenomenon which not only affects core dimensions of farm family life but also the agricultural sector more widely. Intergenerational farm transfer in particular is increasingly viewed as fundamental to the sustainability and development of global agriculture. In the majority of EU countries, the average age of farmers is increasing, while the number of farmers under 40 years of age is decreasing. There is growing concern that this demographic trend may have negative impacts on the agricultural industry because it is younger and not older farmers who are associated with more efficient and effective production practices. The question of what motivates decisions to transfer farms is a complex one, and research to date has not apparently enlightened agricultural policy to the extent that current trends towards an ageing farm population are being managed. This research aims to investigate economic and financial aspects of the policy drivers of farm succession and inheritance in Ireland to understand what it is about the policy environment that is failing to stimulate higher levels of farm transfer. It draws on the Teagasc National Farm Survey data which provides Irish data to the Farm Accountancy Data Network in the European Commission. A hypothetical microsimulation model is used to investigate economic factors of farm transfers, with scenarios created to test these factors and their impacts on the transfer process. The Net Present Value (NPV) of income streams for farmers and their successors are calculated to assess which scenarios have the highest/lowest financial effects. The findings illustrate a range of possible scenarios for farm succession/inheritance, with some results indicating that under current policy retaining a farm until death may be more economically beneficial to a farmer than transferring land before death.
\end{abstract}

Key Words:

Agriculture, policy, succession, inheritance, farm transfer, young farmers 


\section{Introduction}

The process of farm succession and inheritance is highly complex and involves a variety of actors, ranging from family members to professionals providing advice on legal and financial matters (Williams, 2006). In most European countries the family farm model is the predominant form of ownership, meaning that farm transfer commonly takes place generationally. Much of the literature highlights that inheritance is the dominant means of entering farming (Kelly, 1982; Taylor et al., 1998; Hennessy and Rehman, 2007). Factors affecting the decision to transfer a family farm can be both social and economic, with some farmers aiming to ensure all family members are catered for when the farm is transferred, while policy effects and economic concerns of capital taxes and future income can also have a very strong influence on farmer choices. In many developed countries there is concern over the ageing farming population. The average age of farmers in the United States, for example, is 57 (Mills-Novoa, 2011) while almost one third of farm holders in Europe are over the age of 65 (Zagata and Sutherland, 2015). More than half of farmers in the UK are over 55 (ADAS, 2004). In Ireland, the 2013 Teagasc National Farm Survey showed the average age of farmers as 57, with this figure increasing marginally year on year over recent decades, and the number of farmers under 40 years decreasing over the same period of time. This trend has become a source of major concern for the agricultural sector, given the evidence of a positive correlation between younger farmers and farm efficiency/innovation (Potter and Lobley, 1996; Lobley, 2010; Howley et al., 2012). In increasingly globalized and competitive agricultural markets it is argued that the most productive and efficient farmers should be working in the sector (Williams, 2006; Zagata and Sutherland, 2015). In the Irish context, a stifled land market has resulted in very low land mobility and there is a clear pattern of capital accumulation amongst older farmers who are fearful about their financial future and unwilling to transfer their farm assets (Matthews, 2014). Furthermore, state assistance to agriculture provides direct payments to farmers, making it financially beneficial to hold on to agricultural land rather than selling it. The result is a sector dominated by older farmers, with access for young farmer an increasingly problematic issue.

Historically, there has been no substantial long term EU policy put in place to encourage timely transfer of farms or even to assist in the process of gradually handing 
over managerial control to younger farmers. Early Farm Retirement Schemes (EFRS) are one of the mechanism that have been used in attempts to reduce the average farmer age and increase the entry of young farmers. These schemes were optional and mainly taken up by Ireland, France and Greece (Davis et al., 2013). Whilst there have been three rounds of EFRS in Ireland, in 1993, 2000 and 2007 (Teagasc, 2007), all were short-lived and said to have represented little value for money in the sense that they only succeeded in incentivising farmers who were already close to retirement, rather than a fundamental restructuring of the age profile of Irish farmers (although they did show a small but temporary level of success in that regard) (Hennessy, 2014). Similar to the Irish experience, Caskie et al. (2008) found that in France and Greece the EFRSs did not bring about any deep-rooted change to farm transfer trends, as farmers entering the scheme were already close to retirement age. In the UK, Ingram and Kirwan (2011) evaluated the Fresh Start Initiative, a scheme which matched new entrant farmers with retiring farmers as a means of giving younger farmers a start and older farmers a gradual exit strategy. However, this was not seen as hugely successful because there were insufficient profits from some partnerships to sustain two salaries. In the case of New Zealand, the dairy industry does have a well-developed career structure which gives young farmers the opportunity to begin farming and has exit schemes available for older farmers such as phased exit strategies (CIAS, 1996). For dairying, this works on the basis of share milking, which enables younger farmers to begin farming whilst allowing older farmers to gradually exit. Up to $35 \%$ of dairy farms in New Zealand are share farms (Curran, 2014). For all of these schemes, getting to the point of transfer at an earlier stage is the main issue. One obvious incentivising factor for farm transfer concerns the need for the retiring farmer to have sufficient income in the form of a pension or other resources. This is connected in turn to the need for a farm to be viable in order to attract and support a new entrant. The extent to which these are influencing factors in farmers' decisions to retire and transfer their farm is not clear.

A key aim of this discussion is to critically analyse aspects of prevailing policy with a view to identifying the ways in which it influences decisions relating to succession and inheritance. It specifically examines the effect of a range of policy mechanisms including taxation and other financial instruments that control the options for farm transfer and the implications for farmers' decision-making in this regard. It focuses on the Irish context where there has been a recent surge in farming interest on the part of 
young people. Enrolments for agricultural degree and training programmes are at an alltime high, illustrating a strong intention to pursue farming as a primary career choice (Heanue and O'Donoghue, 2014). At the same time the availability of farms to facilitate entry of younger farmers is critically low. The paper first briefly outlines the most common forms of farm succession and inheritance and the ways that these have been typically framed within agricultural policy prescriptions. Then, taking data from the Teagasc Irish National Farm Survey of 2013, it applies a microsimulation model to analyse the financial implications of policies and individual choices on succession and inheritance decision-making. It draws on the concept of risk to interpret the underlying processes driving decisions on succession and inheritance, exploring, for example, the extent to which the policy domain may be contributing to farmers' potential sense of vulnerability and insecurity about post-farming livelihoods and how it is mitigating against attempts to bring about a restructuring of farming in favour of younger farmers.

\section{The concept of risk in the agricultural policy domain}

The main policy instruments available to governments are financial e.g. tax relief or grant based schemes. Essentially, governments use financial incentives to encourage individuals to undertake measures that achieve strategic governmental aims (for example Food Harvest 2020 targets). In the agricultural sector, aims such as environmental conservation are achieved using agri-environmental schemes; these schemes generally benefit farmers economically (Morris and Potter, 1995). Entering financially incentivised schemes reduces uncertainty around income for farmers, thus reducing their perceived economic risks (Koundouri et al., 2009). While it has been argued that farmers are generally risk averse (Groom et al., 2008), there has been no specific research investigating whether or not farmers perceive succession and inheritance processes as a risk. Recent research has indicated that farmers with children between the ages of 5 and 19 tend to be more risk averse (Loughrey et al., 2015). This implies that farmers with potential successors may avoid risk where possible; however, generalisation based on very few studies to date cannot be made.

\section{Overview of current Irish transfer policy environment}

At present, certain financial incentives are in place to encourage early transfer of Irish farms, however, the level of influence and impact the current incentives have on 
succession and inheritance decisions is yet to be determined. These incentives take the form of a range of taxes and duties applying to farm transfer and inheritance.

In Ireland, there are three capital taxes that apply to farm inheritance; they are Capital Gains Tax (CGT), Capital Acquisitions Tax (CAT) and Stamp Duty. CGT applies only to the farmer transferring land out of their name and it is charged at $33 \%$ of the value the property gained between date of acquisition and date of sale/transfer. CAT is applicable to the successor and is charged at $33 \%$ of the value of the property acquired (over and above the relevant relief threshold bands in table 1). Like CGT, CAT reliefs are available up to certain asset value thresholds; these reliefs are dependent on the relationship between the farmer and successor (i.e. son, daughter, niece, nephew etc.). In recent years these thresholds have decreased dramatically (See table 1) leading to a disincentive to take on farm land and assets in some cases, however 2015 marks the first year since 2009 that these limits have increased. Stamp Duty is also applicable to the successor, with this being charged at $2 \%$ of the value of the property, but can be reduced to $1 \%$ based on the relationship of the farmer to successor (McDonnell, 2014). If the successor is a son/daughter of the farmer, and is under the age of 35 with a minimum level 6 agricultural certificate, stamp duty is reduced to zero. Other policy incentives to facilitate earlier transfer in the Irish case are young farmer top ups on Basic Farm Payments (BFP) and other direct payments. Farmers under the age of 40 who have a minimum level 6 agricultural certificate may receive a $25 \%$ top up on their BFP (maximum limit of 50 hectares). 


\begin{tabular}{|l|l|l|l|l|l|l|l|}
\hline Group & $\begin{array}{l}\text { Relationship to } \\
\text { Disponer }\end{array}$ & $\begin{array}{l}8 / 4 / 09 \\
\text { to } \\
31 / 12 / 09\end{array}$ & $\begin{array}{l}1 / 1 / 10 \\
\text { to } 7 / 12 / 10\end{array}$ & $\begin{array}{l}8 / 12 / 10 \\
\text { to } \\
06 / 12 / 11\end{array}$ & $\begin{array}{l}07 / 12 / 11 \\
\text { to } \\
05 / 12 / 12\end{array}$ & $\begin{array}{l}6 / 12 / 12 \\
\text { to } \\
13 / 10 / 15\end{array}$ & $\begin{array}{l}14 / 10 / 15 \\
\text { to } \\
\text { present }\end{array}$ \\
\hline A & Son/Daughter & $€ 434,000$ & $€ 414,799$ & $€ 332,084$ & $€ 250,000$ & $€ 225,000$ & $€ 280,000$ \\
\hline & $\begin{array}{l}\text { Parent*1/Brother/ } \\
\text { Sister/Niece } \\
\text { /Nephew } \\
\text { /Grandchild }\end{array}$ & $€ 43,400$ & $€ 41,481$ & $€ 33,208$ & $€ 33,500$ & $€ 30,150$ & $€ 30,150$ \\
\hline B & $\begin{array}{l}\text { Relationship } \\
\text { other } \\
\text { than }\end{array}$ & & & & & & \\
Group A or B & $€ 21,700$ & $€ 20,740$ & $€ 16,604$ & $€ 16,750$ & $€ 15,075$ & $€ 15,075$ \\
\hline
\end{tabular}

Table 1. Capital Acquisitions Tax Thresholds 2009 - 2013

Farmer response to economically incentivised policy

* In certain circumstances a parent taking an inheritance from a child can qualify for group A threshold

The above describes the current Irish policy situation, but in the Irish context, as in many developed countries, motivating farmers to implement farm level change is a challenge for all agricultural policy formulation. Vanclay (2004) for example asserts that the farming community is heterogeneous, with great variance amongst farmers; therefore, it can be very difficult to create policy that will be accepted or effective in a high number of cases. In his discussion, Vanclay (ibid) lists 27 social principles for agricultural extension within which is the affirmation that 'farmer motivation exceeds any rational economic decision' (p. 214). Briassoulis (2008) alludes to the same notion, in stating that 'the era of 'one-size-fits-all' theories in land use policy and planning is ended' (p.29). One possible reason for this could be the notion that agricultural policy is created on a reactive basis as opposed to a proactive one (Hill, 2000). Norton (2004) also refers to this issue in the context of policy in general, stating that policy reforms only address one issue at a time, as opposed to creating a strategy around what direction the sector affected should take. The most common reactor within agricultural policy often contains some form of economic incentive as farmers in many incidences are

\footnotetext{
${ }^{1}$ *In certain circumstances a parent taking an inheritance from a child can qualify for group A threshold
} 
drawn to policy that proves financially beneficial. One such example would be the agrienvironmental schemes implemented in European countries through Common Agricultural Policy reforms. In the UK, for example, farming in an environmentallyfriendly manner in Environmentally Sensitive Areas (ESAs) was financially rewarded. Morris and Potter (1995) however, refer to ESAs as a 'new source of subsidy' (p.53) that was welcomed by farmers. They question the extent to which such payment amounts to 'buying changes' which would not otherwise occur, thereby strengthening the notion that farmers can in fact be led by financial incentives. Similarly in Ireland, the Rural Environmental Protection Scheme (REPS) became very popular with farmers, especially those on lower farm incomes. Emerson and Gillmor (1999) argue that 'undoubtedly the main reason why many farmers adopt the REPS is financial' (p.244). Similarly, Brouwer (2004) implies that in the area of cross-compliance farmers are economically driven, stating that the correct incentive must be in place to motivate farmer participation in any scheme or programme. However, in the area of succession and inheritance it is yet to be determined if a significant number of farmers can be influenced by such policy change.

\section{Impact of farm viability on transfer}

Farm viability is another distinct issue of relevance for Ireland, with $33 \%$ of farms in 2013 being categorised as vulnerable (Teagasc NFS, 2013) and a further $35 \%$ in the category of 'viable'. Viable here denotes a farm that has the capacity to pay family labour at the average agricultural wage and provide a 5\% return on all non-land assets; while vulnerable denotes that the farm is not viable and neither farmer nor spouse have a source of off-farm income. This can have a strong effect on farm transfer because a low farm income leads to concerns over the farm being capable of providing an income for both the farmer and/or the successor. This can also result in problems of adequate retirement income for the farmer, leading to land retention as a form of financial security.

\section{Succession effects}

While farm viability can be of great importance, the possibility that viability may be increased or decreased is implied by Potter and Lobley (1996). They have coined the terms 'succession, successor and retirement effects' with each having a different impact 
on a farm's trajectory. The succession effect implies that farmers with successors are more likely to invest or expand in anticipation of a takeover of the farm by a son or daughter than those who do not have a successor. In contrast to this, Loughrey et al. (2015) found that farmers with more children between the ages of 5 and 19 were more risk averse. While risk and expansion are not the same phenomenon they may be correlated; indicating further research may explain the variance of these results. Potter and Lobley (ibid.) argue that 'farmers without successors and those with low expectation of succession seem significantly more likely to be disengaging from agriculture' (p.329). Several authors have attained research results which confirm the existence of the succession effect (Burton and Walford, 2005; Shawyer, 1990; Calus et al., 2008). The successor effect refers to the positive impact which a successor can have on a farm once he or she becomes actively involved in the running of a farm and decision-making processes. This also includes the period in which a successor assumes full or gradual managerial control. Generally young farmers returning from agricultural education are more aware of new technologies or wish to implement change on their own farms resulting in increased efficiency and output (Potter and Lobley, 1996). The final effect mentioned by Potter and Lobley (1996) is the retirement effect, which generally has a negative impact on farms i.e. the process of semi-retirement tends to be characterised by de-intensification and liquidation of assets if there is no successor present. It refers to the period in which a farmer is coming near the end of his or her farming career, where the impacts for the farm are most serious when a successor has not been identified.

While the positive effects of the presence of a successor can generally be measured (e.g. farm expansion), other immeasurable outcomes can stem from the succession effect. Fischer and Burton (2014) contend that farm succession as socially-constructed phenomenon necessitates a sustained engagement and process of socialisation of the successor with the farm from early childhood in order to form the kind of "successor identity' (pp. 417) needed to effect farm takeover (Brandth and Overrein, 2013). Drawing on the social constructivist framework of social identity to explain the formation of farming identities, they develop the concept of endogenous succession cycles to interpret the trajectory that underpins succession outcomes. This is built on three intertwined and mutually-reinforcing processes; the construction of successor identities; the progression on the farm 'ladder'; the development of farm business 
identities (424). Under this social constructivist perspective, succession is therefore not so much an outcome of a set of rational choices or of specific policy interventions, but more about how the successor's gradual identity development has come to reflect the sustained and complex set of experiences, interactions and expectations that relate to that specific farm. For them, the policy requirements of what is essentially a farmspecific phenomenon are measures that protect and sustain endogenous cycles which in turn ensure the ongoing socialising of particularly during hardship periods or other farm crises, or that may be disrupted due to farm modernization or regulatory change.

In many cases farmers are reluctant to retire and thus retain farm ownership/control well past normal retirement age. This in turn affects the age at which a successor may become actively involved in farm decision making. There are various reasons of both economic and non-economic origin that contribute to the reluctance of farmers to retire. Riley (2012) extensively discusses the impact of farm retirement on social and cultural identities, particularly of males in farming, where farming and social relations were tightly intertwined and the idea of disrupting these is resisted, where there are conflicted emotions about cutting generational ties to farming, and where adaptation to life away from farming proves difficult. Conway et al. (2016) similarly allude to the noneconomic reasons that influence such a decision, including the impact on a sense of personal identity closely connected to farming as the way of life and unwelcome reminders of mortality. These effects are all considerable for farm families, but in turn each of the effects mentioned could potentially impact on global agricultural output levels. Figures 1 and 2 show the increase in farm income until the farmer reaches his or her late 30s, with income decreasing thereafter. This indicates that for a farm transfer to have a positive economic impact on the farm, transfer should ideally take place before the successor is 40. This data concurs with the idea of a succession and successor effects. A slight peak appears around age 50 for both farm systems, which may be a result of farmers having identified successors by this age and thus begin expansion. However, a dip occurs at age 55 contradicting this argument. Further probing of NFS data may reveal the reason for this. 


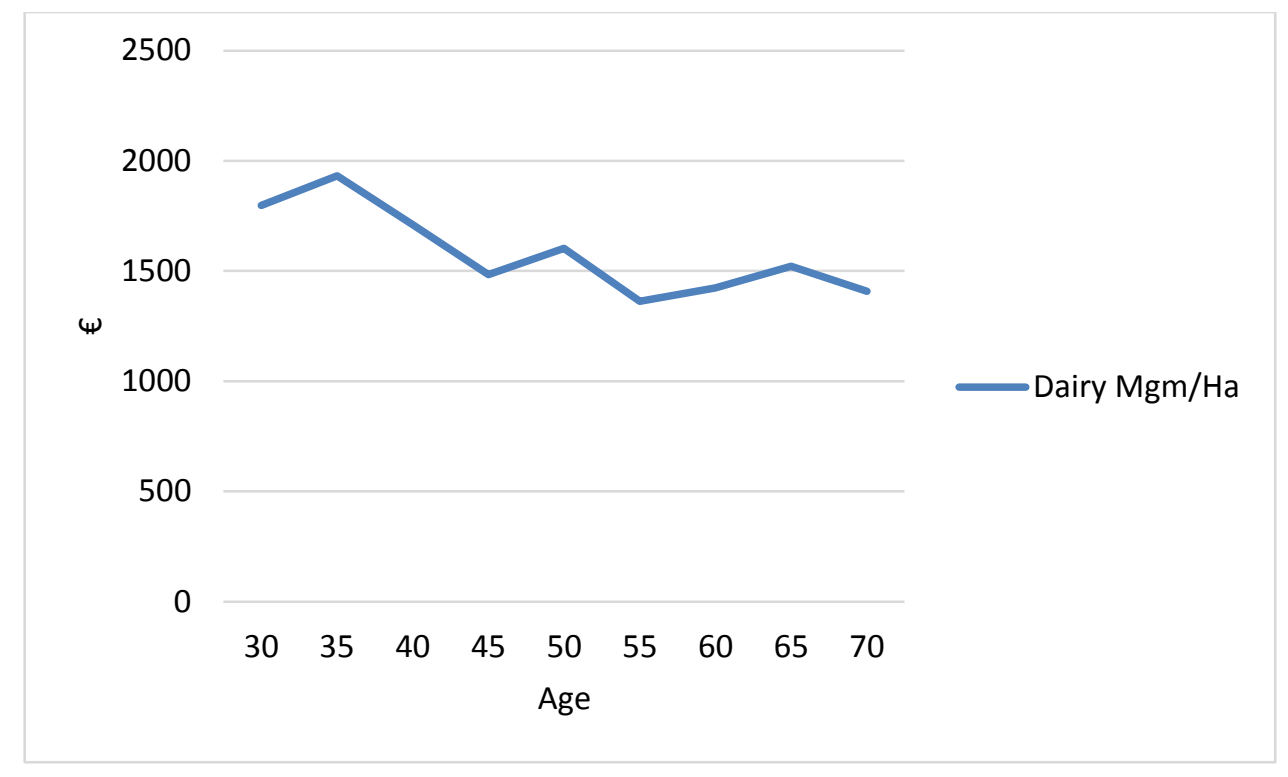

Figure 1 Dairy market gross margin per hectare, by age ( Teagasc NFS, 2013) ${ }^{2}$

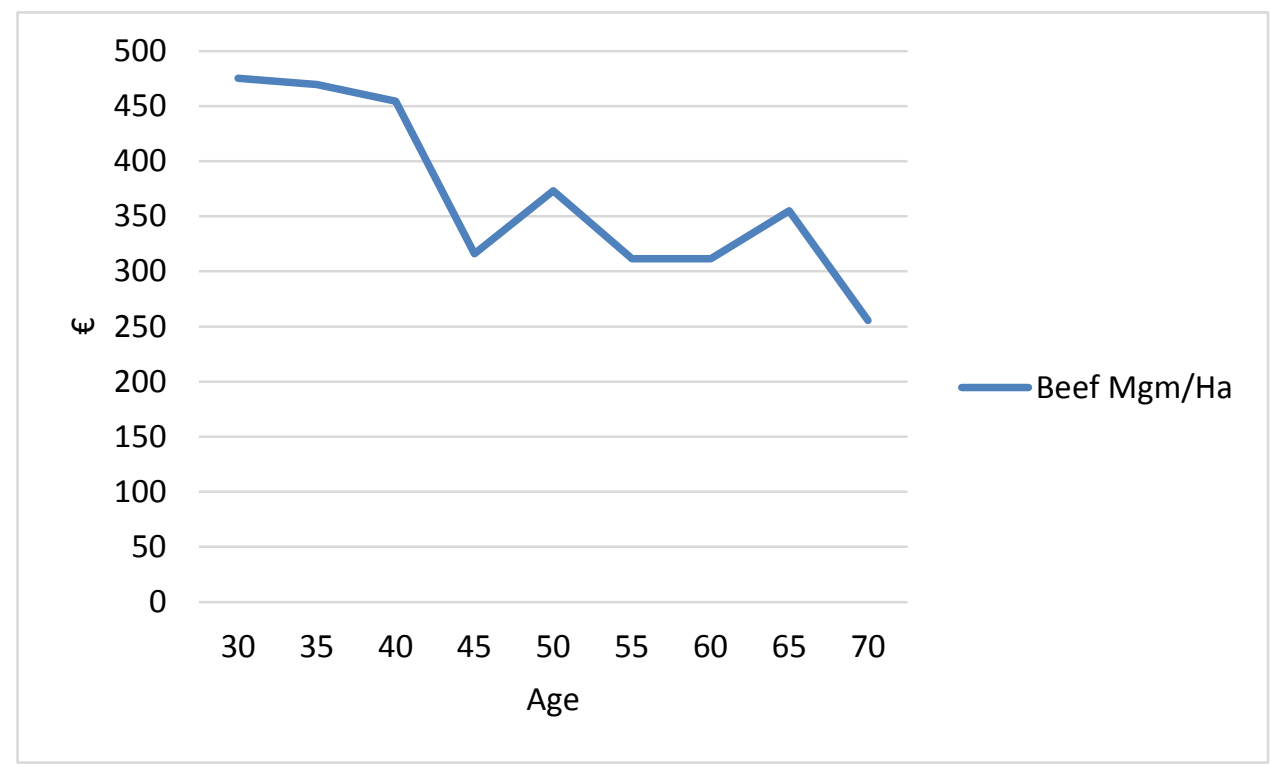

Figure 2 Beef market gross margin per hectare, by age (Teagasc NFS, 2013)

\section{Methodology and Data}

The area of farm succession and inheritance lends itself to a high level of complexity given the factors involved such as the wide-ranging impact of such a decision on the lives of the farmer, successor, and their families (Inwood and Sharp, 2012). Nonetheless, the levels of complexity must be extracted so that the chosen scenarios can be used to analyse the economic impact of different routes to succession and

\footnotetext{
${ }^{2}$ Observations for farmers younger than 30 and older than 70 are too low to be graphed.
} 
inheritance. Microsimulation is the most appropriate methodological approach as it allows for complexity to be removed to an extent and an assessment of different changes to be made at a micro level (O'Donoghue et al., 2014). This method facilitates the projection of income streams for both parties, whilst allowing for farm level changes (such as income increase/decrease and farm size adjustment) to be made for each scenario. Methods used will be outlined further in this section.

\section{Measures of Impact/Analytical Measure}

Net Present Value (NPV) is defined as 'the difference between the present value of all cash inflows (benefit) and the present value of all cash outflows (cost)' (Jechlitschka et al., 2007, p.113). Values such as income stream will be discounted to the present value. Bacidore et al. (1997) argue that the NPV of a business can be greatly affected by strategies adapted for the future of the business, here; the strategy of the farm business is based on the succession/inheritance decision made. Using NPV's for the farmer and successor will indicate the future income streams both would acquire in the scenarios modelled. A Net Present Value (NPV) figure will be calculated for each scenario using a microsimulation model; the outcomes will then be compared focusing on the policies and motivations which affect each decision. Together with the NPV, a replacement rate will be calculated for the farmer in each scenario. This will be calculated by dividing income at age 66 by income at age 65 i.e. retirement replacement ratio.

$$
\text { Replacement ratio }=\frac{\text { Income at } 66}{\text { Income at } 65} \times 100
$$

This formula is an edited version of the replacement ratio formula presented by Turley and Maloney (1997). The average net replacement rate for an Irish male is 45\% (OECD, 2012), with the average for all OECD countries being $66 \%$.

\section{Policies and motivations}

Modelling different scenarios of succession and inheritance decisions allow for the comparison of NPVs, which will result in the most economically beneficial succession and inheritance scenarios to be established. Each scenario is affected differently by policy and the decisions taken are a result of various motivations. Table 2 lists the main policies and motivations that will affect each scenario. 


\begin{tabular}{|l|l|}
\hline \multicolumn{2}{|c|}{ Main policies and motivations affecting succession/inheritance } \\
\hline \multicolumn{1}{|c|}{ Policies } & \multicolumn{1}{c|}{ Motivations } \\
\hline CAT - Agricultural relief & Age \\
\hline CGT - Retirement relief & Income \\
\hline Stamp Duty - Consanguinity relief & Health \\
\hline Young Farmer Top Ups & Increased leisure time \\
\hline & Financial security \\
\hline & Education \\
\hline
\end{tabular}

Table 2. Main policies and motivations affecting succession/inheritance

\section{Base farm}

To ensure each scenario is comparable two base farms will be used for this research, using capital taxation rules from 2014. The farms will be based on the NFS average data for a cattle rearing and dairy systems, as these are the most dominant farm systems in Ireland. In the case of the cattle rearing farms modelled, all farmers/successors qualify for farm assist payment based on the low income level. The figures are as follows:

\begin{tabular}{|l|l|l|l|}
\hline \multicolumn{2}{|c|}{ Average Cattle Rearing } & \multicolumn{2}{c|}{ Average Dairy } \\
\hline Family Farm Income & $€ 9,541$ & Family Farm Income & $€ 62,994$ \\
\hline Machinery & $€ 17,717$ & Machinery & $€ 57,218$ \\
\hline Livestock (Breeding) & $€ 26,534$ & Livestock (Breeding) & $€ 85,569$ \\
\hline Trading & $€ 16,855$ & Trading & $€ 27,867$ \\
\hline Land and Buildings & $€ 577,615$ & Land and Buildings & $€ 973,079$ \\
\hline UAA & 38.1 ha & UAA & 55.4 ha \\
\hline Total cattle number & 61 & Total cattle number & 143 \\
\hline
\end{tabular}

Table 3. Average Cattle Rearing/Dairy Data ( Teagasc NFS,2013)

Farmer and successor characteristics used will be as in table 4; these characteristics are applied so that the farmer and successor qualify for maximum capital tax reliefs. A farmer aged 35 or under is considered a young farmer for capital tax reliefs. In the scenarios modelled the successor will be the child of the farmer. While a farmer over 65 is considered to be at retirement age and is eligible for a contributory state pension (hereafter referred to as state pension) at age 66 (depending on contributions made, for all scenarios it is assumed the farmer has made full contributions). In addition, modelling with the farmer being aged 65 will allow for a comparison of pre and post 
retirement income. An age based tax credit is also available in Ireland on reaching age 65. The characteristics used here are:

\begin{tabular}{|l|l|}
\hline \multicolumn{1}{|c|}{ Farmer } & \multicolumn{1}{c|}{ Successor } \\
\hline Age: 65 & Age: 35 \\
\hline Married & Education: Level 6 Ag. Education \\
\hline Pension: Contributory & Single \\
\hline No off farm job & Off farm job $(€ 25,000$ income $)$ \\
\hline
\end{tabular}

Table 4. Farmer/Successor characteristics

\section{Scenarios}

The scenarios selected for this research are based on the predominant routes to succession that are available in Ireland and the most highly documented routes in literature (Hennessy and Rehman, 2007; Kelly, 1982). As illustrated above, there are a range of motivations and policies affecting the succession and inheritance decision. Many of the factors listed in table 2 will be significant in the hypothetical scenarios.

\section{Expected outcomes}

It is expected that scenarios where tax reliefs are optimised will be the most economically beneficial to the farmer and successor, however, ages, income levels and asset values should have the biggest effect on policy drivers. Policies aimed at increasing land mobility should minimise land transfer costs and incentivise farmers to transfer land earlier, however, direct payments may make it more economically beneficial to the farmer to delay transfer until death. These payments may result in land retention by older farmers, as they provide a steady source of income into retirement, Replacement rates for some farmers may be lower than the averages mentioned above, based on a common lack of strong retirement income planning among the farming community. In section 4 the outcomes of each scenario will be discussed.

Focusing on two hypothetical farms will allow for the sensitivity of farms to policies to be tested while avoiding the complications that would arise were this study to be undertaken on a real farm. Variables such as farm size, income, and livestock units can be held constant which may not always be the case in reality. Adjusting aspects of the farms will test the effects of succession/inheritance policies on income (including future income represented as NPV) and capital tax implications. 


\section{Hypothetical microsimulation modelling}

Microsimulation models use data on micro-units (e.g. households, firms, farms, etc.) to simulate the effect of policy or other socio-economic changes on the population of micro-units (Mitton et al. 2000). The need for microsimulation arises from the difficulty of observing simultaneously the outcomes for the same micro-unit under a treatment and in the absence of a treatment (e.g. policy change), and also crucially as a tool to understand the complexity of a policy problem. The result of the microsimulation models can be affected by many factors, which makes it difficult to illustrate the effect of a single factor. Hypothetical models, on the other hand, often focus on a particular scenario under certain predefined assumptions. This allows the model developer to examine a simplified version of the simulated observation (O'Donoghue et al., 2014). Microsimulation techniques have become a much used instrument for their ability to provide an assessment of differing scenarios and facilitate decision making (Spadaro, 2007). In this case, microsimulation will be used to inform decisions regarding farm transfer. Focusing on a hypothetical farm will allow for the sensitivity of farms to policies to be tested while avoiding the complications that would arise were this study to be undertaken on a real farm. Farm level decisions are not always rational or economically driven (Vanclay, 2004; Howley et al., 2012), but this method facilitates the simulation of decisions based on economic incentive as opposed to basing decisions on non-economic phenomena. Adjusting aspects of the farm will test the effects of succession and inheritance policies on income and capital tax implications.

\section{Data requirements}

The data being used here is hypothetical farm level data, each scenario described above requires information on a range of variables, namely: age of farmer/successor, incomes for both parties (on and off farm), type of pension (farmer/spouse), asset values (land, machinery, livestock, direct payments received, and personal asset values). This data will then be used in the model to generate a NPV for both parties involved. As discussed in section 2, NFS average figures for cattle rearing and dairy farms will be used for the base farm, with farmer and successor ages and incomes being simulated so that they qualify for maximum capital tax reliefs. Section 3 will describe each scenario to be modelled in detail. 


\section{Results}

\section{Routes to succession}

As mentioned above, there are a range of routes to farm succession/inheritance; nonetheless, there are only a certain number of choices available to both farmers and successors. The variety of transfer options available were considered leading to the scenarios below, these scenarios will be modelled in section 4. In the scenarios presented, it is assumed that the NFS average figures for cattle rearing and dairy apply. For clarity of results, scenarios labelled 'A' will apply to cattle rearing systems, and scenarios labelled ' $\mathrm{B}$ ' will apply to dairy systems. As mentioned, there are a range of other possible situations involving farm transfer; however the two shown here best illustrate the policies associated with farm transfer and how they may have an effect on succession and inheritance processes. Below the scenarios are outlined.

\section{Scenario 1 - transfer at death}

In this scenario the farmer retains ownership and use of all farm assets until death, resulting in financial security and retirement income for his lifetime. Transfer on death results in no CGT applying to the transfer, as this tax applies to the farmer only. This can be a financial burden for those transferring their land to another party. The farmer will acquire the state pension (contributory) from the age of 66 which will be supplemented by farm income. On death of the farmer, the successor will inherit all farm assets. This scenario is not uncommon in farming with farmers often being highly reluctant to retire, one reason for this being a lack of available retirement income (Riley, 2014). In addition, Terres et al. (2015) highlight that farmers in general will not exit agriculture unless their income becomes very low. In the case of this scenario the farmer's income should increase on reaching age 66 as a result of farm income and pension combining. Thus, there would be little incentive for the farmer in this situation to transfer the farm before death.

\section{Scenario 2 - transfer at death (destocking and retaining payments)}

The farmer here will destock to the minimum level necessary so that he/she may receive Less Favoured Area (LFA) payment (0.15 livestock units/Ha), retain their SFP, and still acquire a state pension. The pension figure here will depend on Pay Related Social 
Insurance (PRSI) contributions, the number of dependants the farmer has, their age and if they are living alone. The maximum weekly pension allowance here would be $€ 230.30$ and the minimum would be $€ 92$. The farmer is motivated to destock so as to cut down on labour input and thus increase leisure time. Retaining ownership of the farm will result in the farmer remaining eligible for the LFA and SFP, whilst also providing financial security to provide for long term care requirements should they arise. Gullifer and Thompson (2006) assert that farmers may disengage with their work as they age; this is essentially what is occurring in this scenario. Similarly, Kristensen et al. (2004) found that older farmers are more likely to engage in extensification and in some cases land abandonment. However, the factors listed earlier in table 2 would also contribute to the farmer's decision to destock and reduce workload.

\section{Outcomes}

The scenarios described above were modelled on both a cattle and dairy farm using average farm system data from the 2013 Teagasc NFS. The results obtained from both systems for the two hypothetical scenarios are presented here (scenarios 1 and 2 - for cattle and dairy systems). Selection of the scenarios presented were based on the impact of changes in farming decisions on the income streams and income/capital taxes payable as measured by the NPV for the farmer and his/her successor. Table 5 shows the total NPV for each scenario, and also the individual NPV's for farmer and successor. In this section analysis of the results will be discussed.

\begin{tabular}{|l|l|l|}
\hline Scenario & NPV & $€$ \\
\hline AA & NPV - Farmer & 481,175 \\
\hline & NPV - Successor & 378,506 \\
\hline 1B & Total & 859,680 \\
\hline & NPV - Farmer & 957,801 \\
\hline & NPV - Successor & 410,382 \\
\hline 2A & Total & $1,368,183$ \\
\hline & NPV - Farmer & 519,356 \\
\hline & NPV - Successor & 234,739 \\
\hline 2B & Total & 754,095 \\
\hline & NPV - Farmer & 639,177 \\
\hline & NPV - Successor & 383,567 \\
\hline & Total & $1,022,745$ \\
\hline
\end{tabular}

Table 5. Net Present Values for farmer and successor 
Scenario $1 A$ - transfer at death (cattle rearing)

The results for this scenario, an average cattle rearing farm, illustrate that on a farm where asset values and farm incomes are low then consequently capital taxes and income taxes are not payable or minimal. The NPV in total for such a farm is low. Tables 6 and 7 illustrate all income streams, income taxes and capital taxes for both the farmer and successor for the farm being transferred.

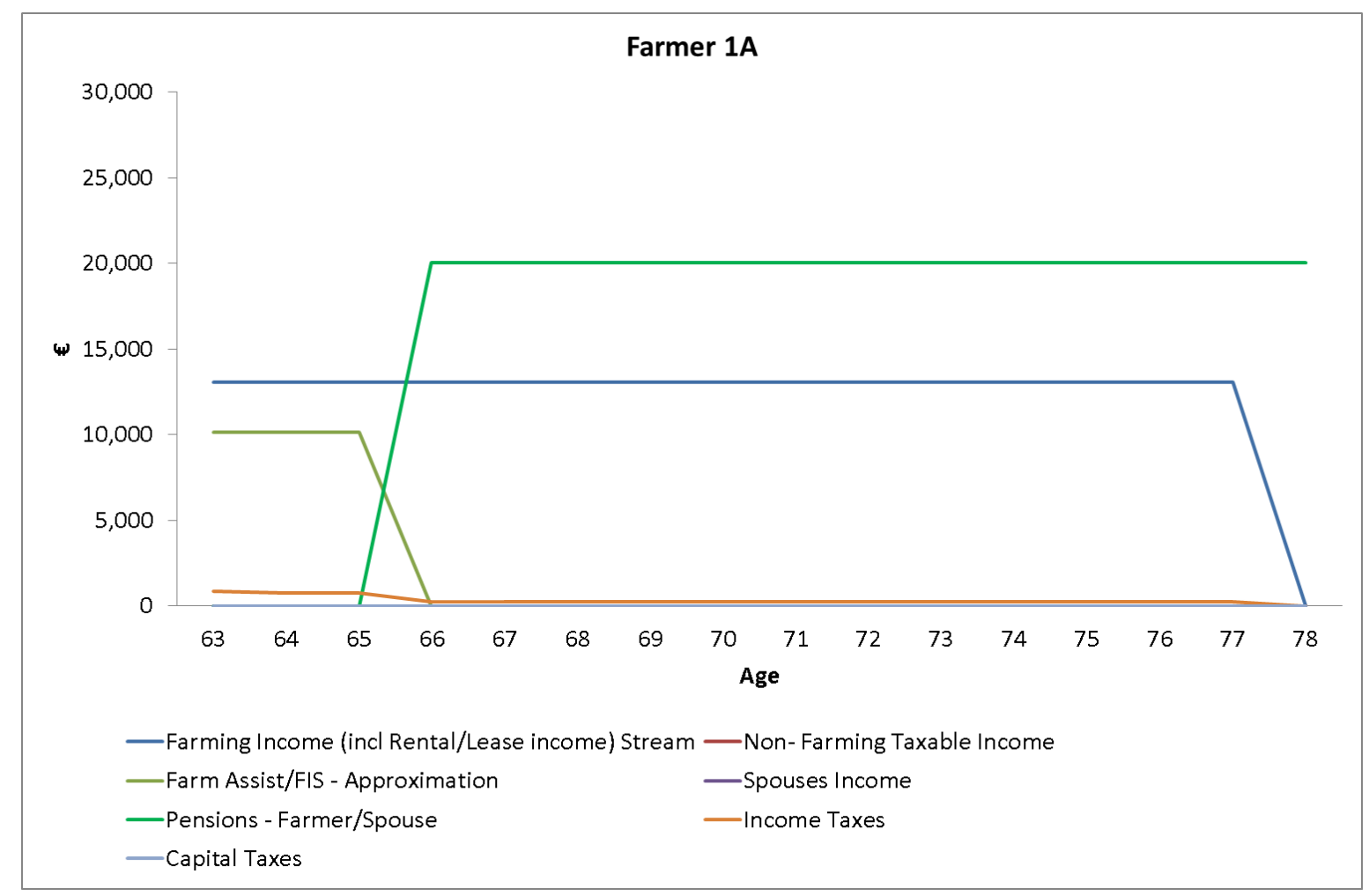

Figure 3 Farmer - Scenario 1A: Cattle rearing farm transferred at death 


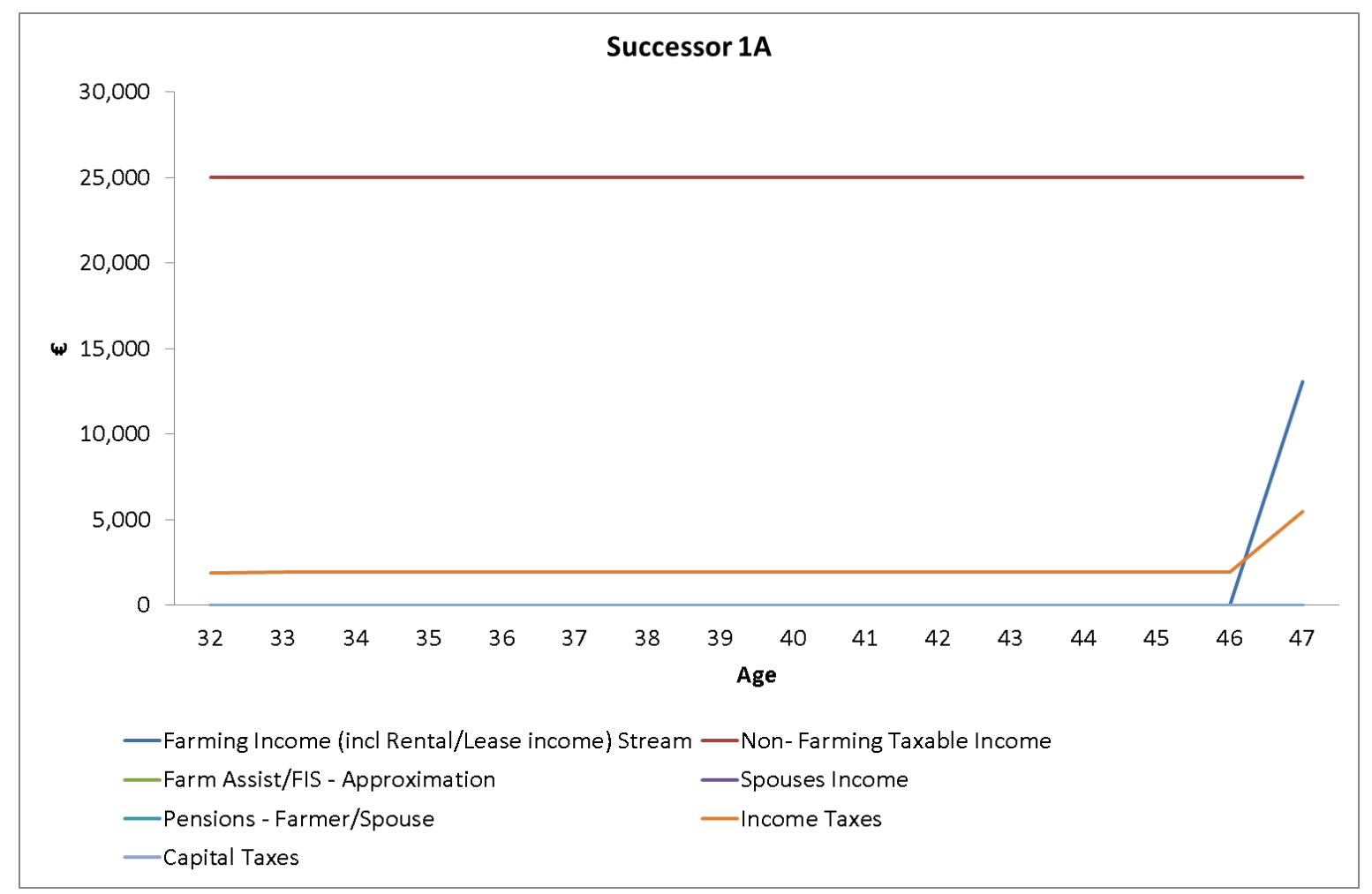

Figure 4 Successor - Scenario 1A: Cattle rearing farm transferred at death

For the farmer, income remains relatively stable from age 63 to 65. An annual exemption allows those who are over 65 and married to earn up to $€ 36,000$ tax free. Therefore, on reaching age 65 this tax exemption kicks in and so leads to a reduction in income tax payable and thus an increase in income. At age 66 there is a further income increase owing to the farmer being eligible for a state (contributory) pension. This state pension is not means tested and the farmer is therefore able to retain his/her farming income until death while also receiving the pension (for themselves and their spouse). As a result, income increases at 66 as the farmer's pension and farming income combine. The farmer transfers the farm on death and is therefore not liable for CGT on the assets disposed of. The farmers spouse continues to receive a pension. In the case of the successor off farm income remains stable as they have an off farm job, when the farm is inherited income stream and income taxes increase. The farm is inherited at age 47; which is above the age to qualify for reliefs on CAT and Stamp Duty; however the value of the farm is relatively low so no capital taxes apply here. 
Scenario $1 B$ - transfer at death (dairy)

This scenario is the same as $1 \mathrm{~A}$ but using average dairy figures, therefore incomes and asset values are higher. The results present a similar pattern to $1 \mathrm{~A}$, albeit at higher levels.

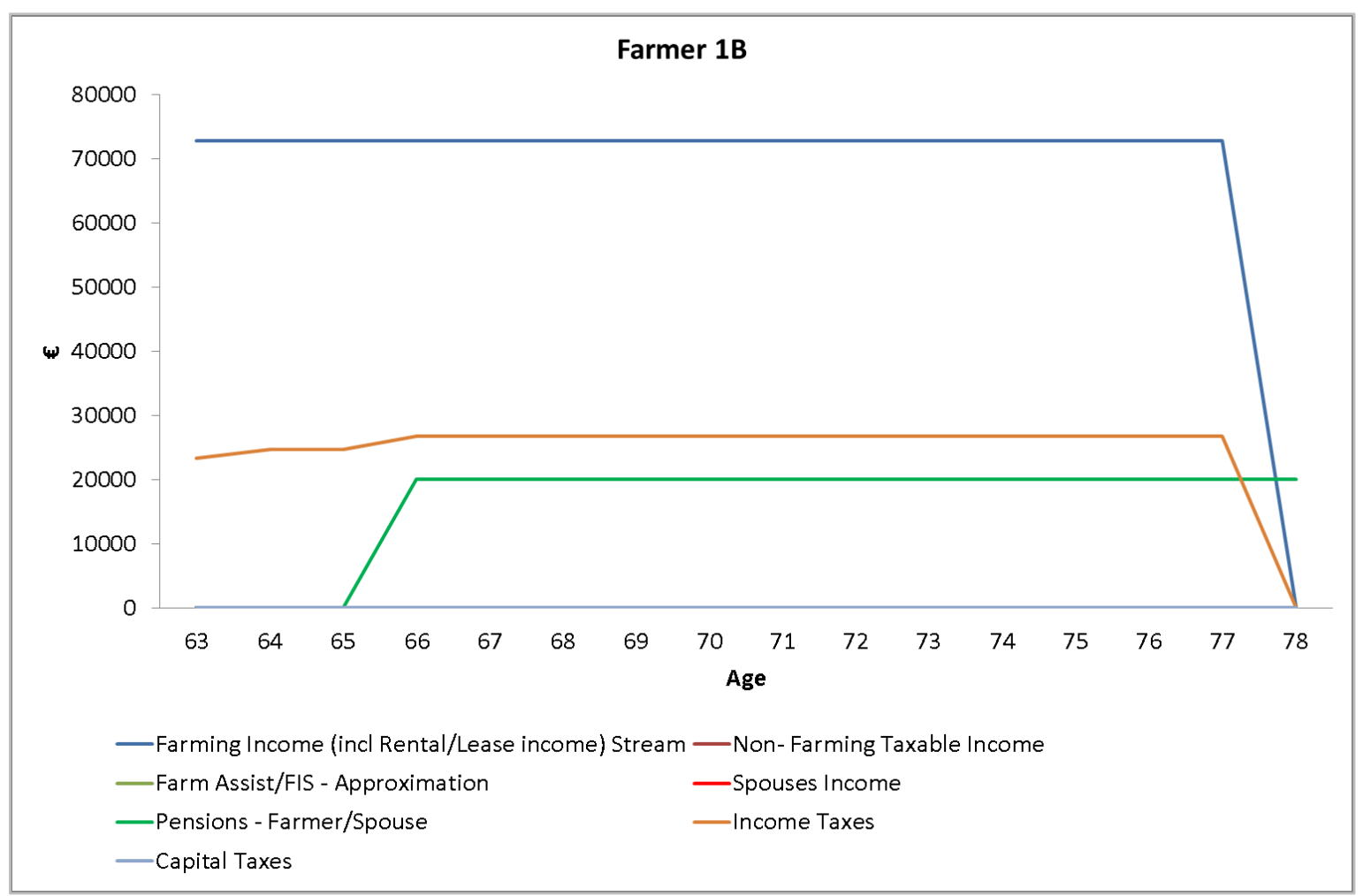

Figure 5 Farmer - Scenario 1B: Dairy farm transferred at death 


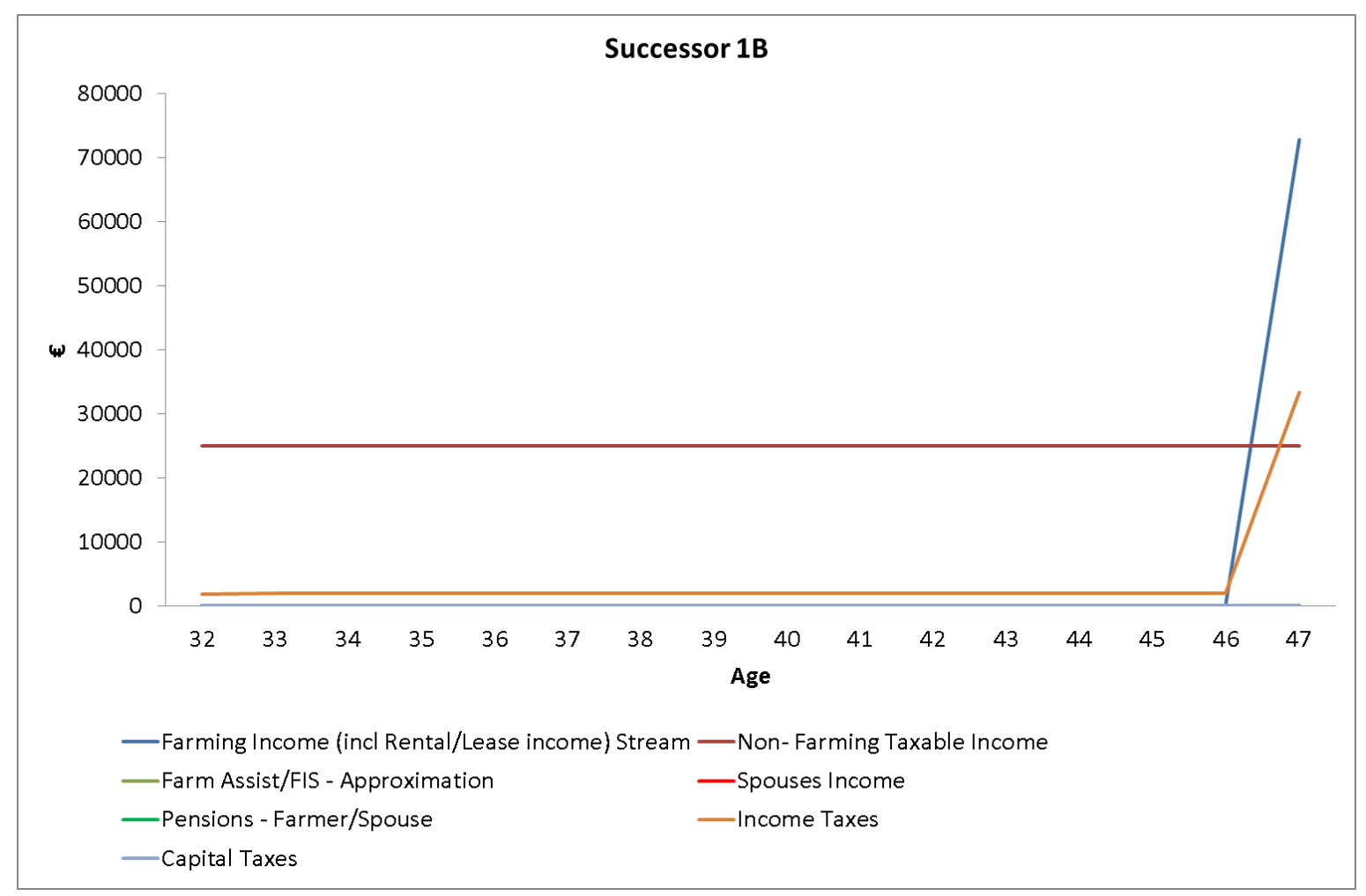

Figure 6 Successor - Scenario 1B: Dairy farm transferred at death

The farmer's income increases when they reach retirement age, while the successor's income does not increase until the farm is inherited. Interestingly, even with higher asset values and incomes, the successor does not have to pay any capital taxes on inheriting the farm as a result of capital tax reliefs.

Scenario $2 A$ - transfer at death (retaining assets and payments) (cattle rearing)

Similarly to scenarios $1 \mathrm{~A}$ and $\mathrm{B}$, the farmer retains all payments and assets, and the successor inherits the farm when the farmer is deceased. However, the farmer destocks from $1.06 \mathrm{LU} / \mathrm{ha}$ to $0.15 \mathrm{LU} / \mathrm{ha}$ at age 65 so as to retain LFA payments and SFP while minimising labour. The successor has an off farm job and does not acquire the farm until the farmer is deceased. 
Farmer 2A

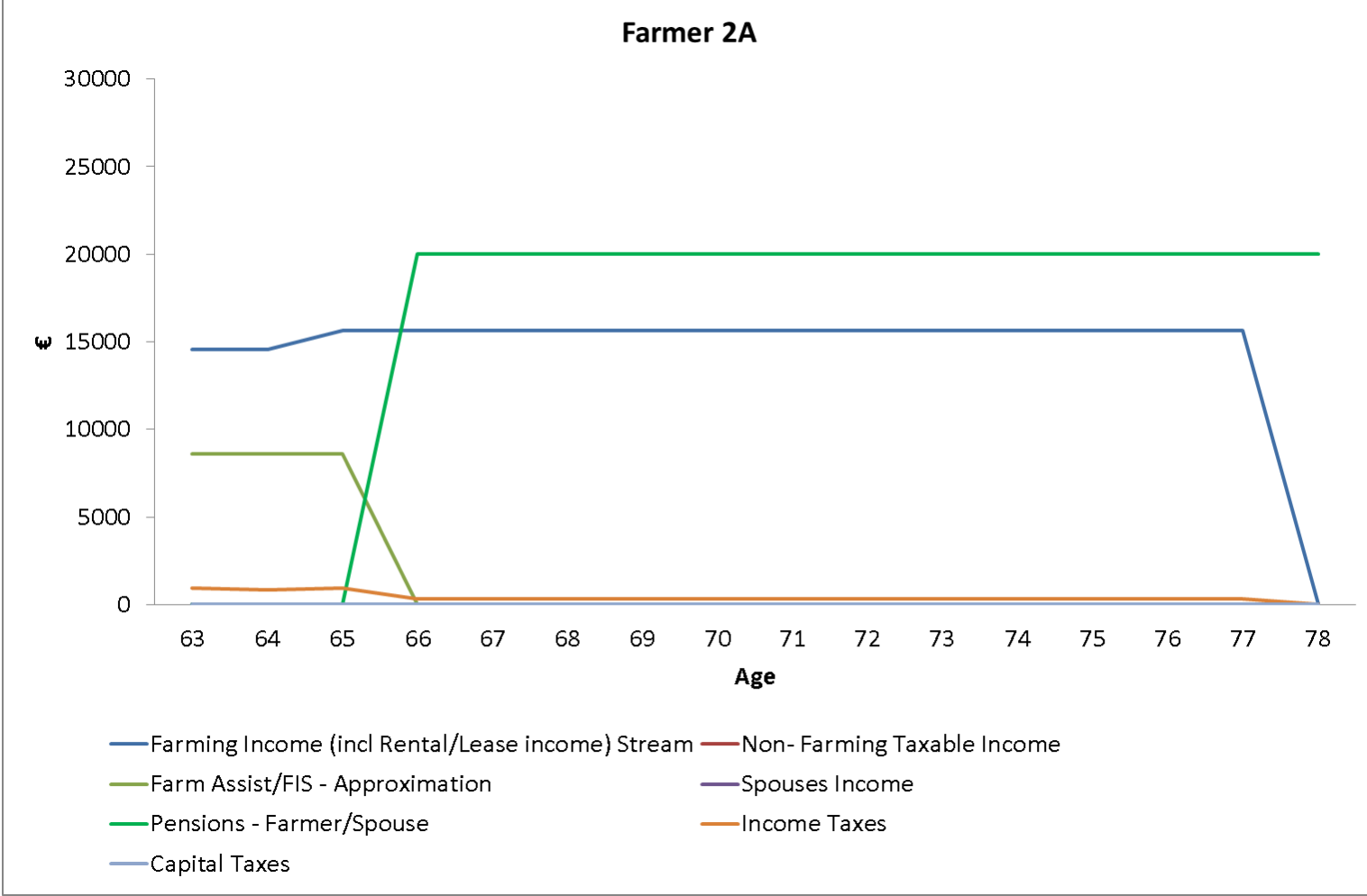

Figure 7 Farmer - Scenario 2A: Cattle rearing farm transferred at death, farmer destocks to $0.15 \mathrm{LU} / \mathrm{ha}$

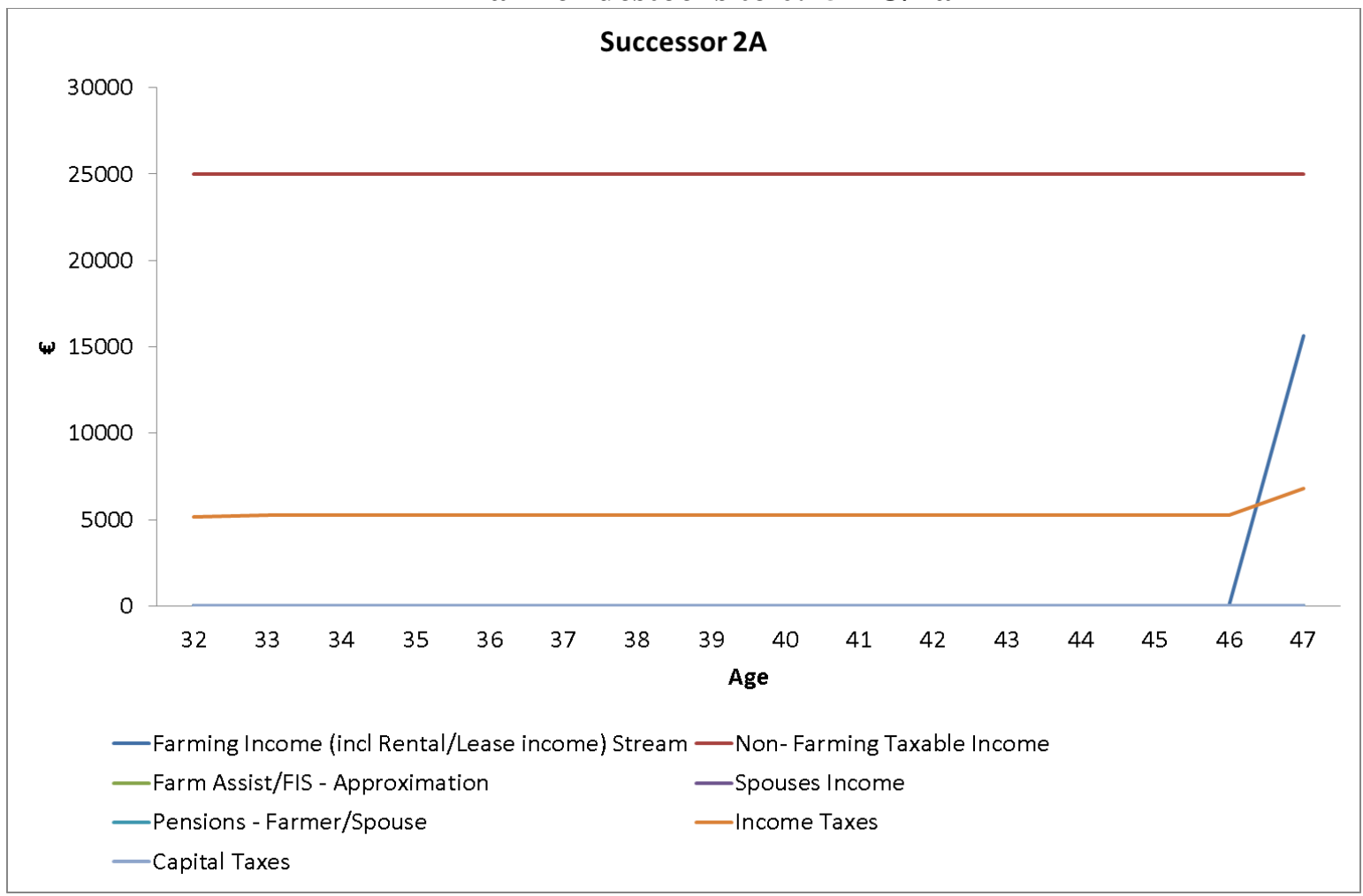

Figure 8 Successor - Scenario 2A: Cattle rearing farm transferred at death, farmer destocks to $0.15 \mathrm{LU} / \mathrm{ha}$ 
The farmer acquires state pension at 66 as with the scenarios above. However, the increase in income is greater because the farmer has destocked from $1.06 \mathrm{LU} / \mathrm{ha}$ to 0.15 LU/ha, thus reducing costs which impact the level of income (costs here are calculated based on livestock units, therefore direct costs are reduced on destocking). Pension and farm income combine to create the increased income stream for the farmer. The successor's income remains stable given the presence of an off farm job, with an increase at age 47 when the farm is inherited. Capital taxes do not affect the successor here, as the value of assets being transferred are below the thresholds.

Scenario $2 B$ - transfer at death (retaining assets and payments) (dairy)

As with $2 \mathrm{~A}$, the farmer destocks to $0.15 \mathrm{LU} / \mathrm{ha}$ (from $1.8 \mathrm{LU} / \mathrm{ha}$ as this is the average stocking rate for a dairy farm) so as to retain LFA payments and SFP while minimising labour. The successor has an off farm job and does not acquire the farm until the farmer is deceased. In this case, the asset values and income streams are based on average dairy farm figures from the 2013 Teagasc NFS. 
Farmer 2B

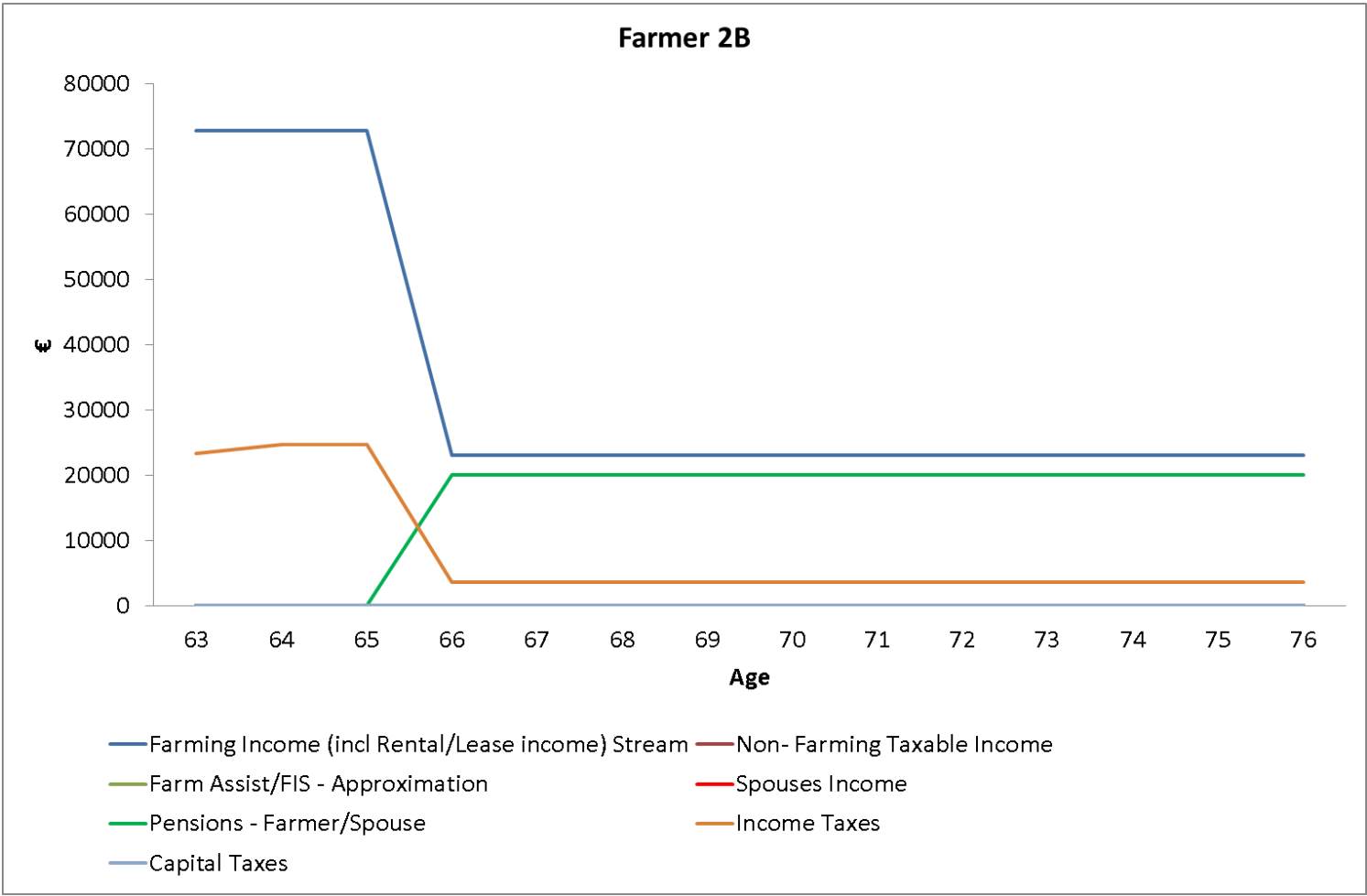

Figure 9 Farmer - Scenario 2B: Dairy farm transferred at death, farmer destocks to $0.15 \mathrm{LU} / \mathrm{ha}$

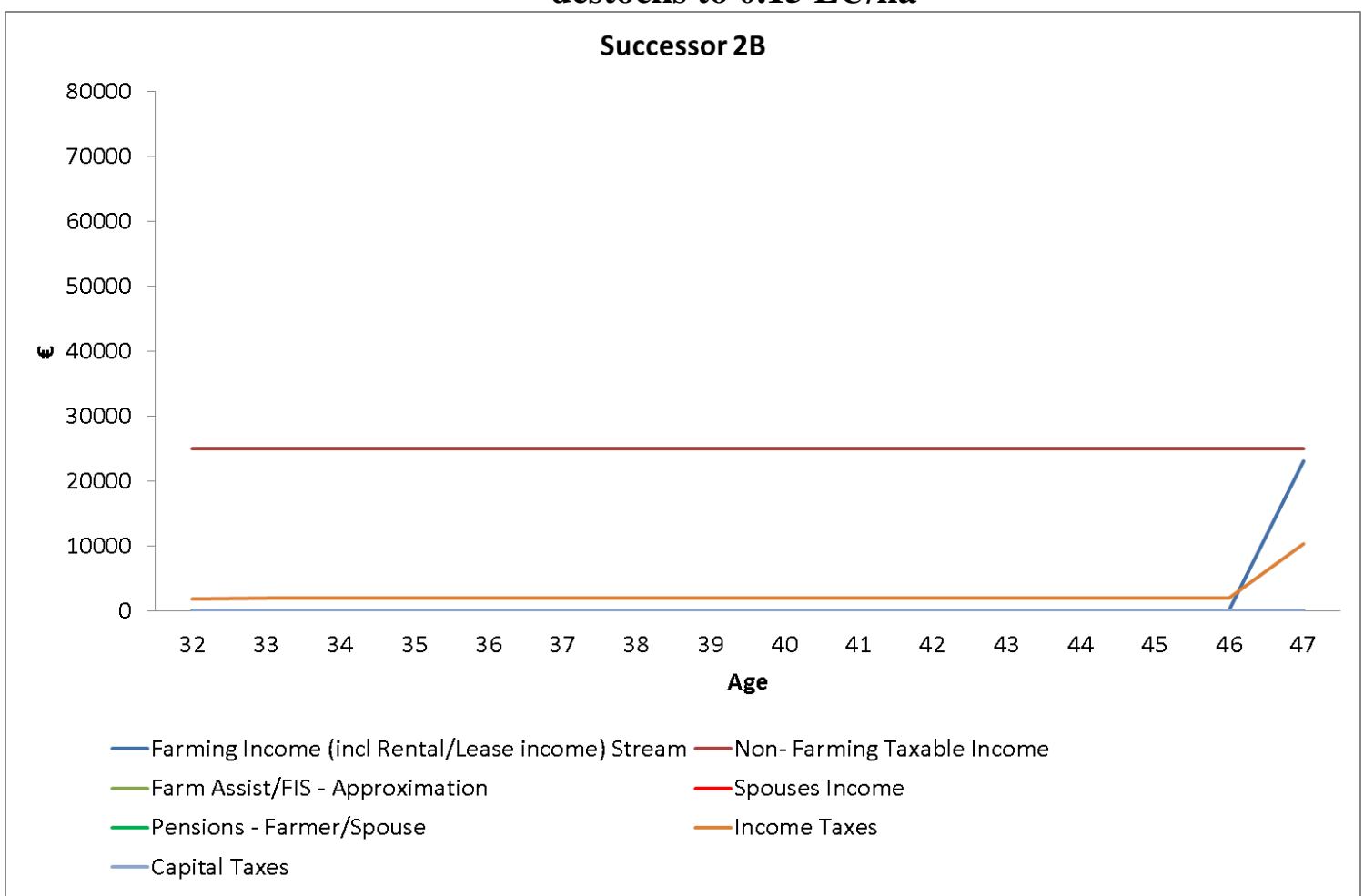

Figure 10 Successor - Scenario 2B: Dairy farm transferred at death, farmer destocks to $0.15 \mathrm{LU} / \mathrm{ha}$ 
For the farmer in this scenario, destocking from $1.8 \mathrm{LU} / \mathrm{ha}$ to 0.15 and acquiring payments does not result in the income increase modelled in scenario 2A. In contrast, income decreases when the farmer destocks on reaching the age of 66. Income tax decreases significantly for the farmer at this age as pension income and farm payments make up the main income stream as opposed to farm income alone. Also age credit is applicable from 65 reducing taxes further. The successor does not benefit from farm transfer until the farmer is deceased. Then income stream and thus income taxes increase when off farm income and farm income are combined. Even with average dairy data, capital taxes do not apply to the successor as the asset values fall below the applicable relief thresholds (for parent to child transfers). In spring 2015 EU milk quotas were abolished (Lapple and Hennessy, 2012) giving rise to opportunities for dairy farmers in the EU to expand. This in turn increases the possibility of greater profits in the dairy sector meaning a higher likelihood of dairy farms being capable of generating sufficient income for two generations.

\section{Farmer replacement rates}

For all scenarios, a replacement rate for the farmer was calculated by placing total income at 65 over total income at 66 (when pension age is reached). This allows us to assert whether the farmer benefits economically under each scenario. Table 6 presents the replacement rates (in percentages) of the incumbent farmer in each scenario.

\begin{tabular}{|l|l|}
\hline Scenario & Replacement rate (\%) \\
\hline 1A & $143 \%$ \\
\hline $2 \mathrm{~A}$ & $165 \%$ \\
\hline 1B & $127 \%$ \\
\hline 2B & $59 \%$ \\
\hline
\end{tabular}

Table 6. Replacement rates for farmers

For all scenarios the replacement rates are high compared to the average replacement rate for Ireland (45\%) as discussed earlier. The highest replacement rate is for scenario 2A $(165 \%)$ in this case, the farmer retains his/her cattle farm income into retirement combined with pension income (as opposed to pension replacing farm income). In addition to this, the farmer destocks to a minimum level of $0.15 \mathrm{LU} / \mathrm{ha}$ so as to retain LFA payments and BFP. Scenario 2B has the lowest replacement rate at 59\%, this is a result of the dairy farm destocking to $0.15 \mathrm{LU} / \mathrm{ha}$ from $1.8 \mathrm{LU} / \mathrm{ha}$, meaning a reduction 
of income for this farm. Even though replacement rate is the lowest in the sample, it remains well above the Irish average of $45 \%$. Also, the farmer's leisure time would be greatly increased as a result of the low stocking rate, with labour requirement decreasing as a result.

\section{Discussion and Policy Recommendations}

While succession and inheritance can be a highly complex area, the deconstruction of the problems associated with these processes will aid policy makers in generating more effective solutions. Notably, the policy making process requires a level of assessment prior to this occurring. Based on the findings of this research, there are clear economic concerns regarding farm succession and inheritance with the the most notable concerns being the ability (or inability) of a farm to generate enough income to support both a farmer and their successor, and also the residual income of the farmer should they transfer the farm prior to death. Incidence of capital taxation has little economic impact in any of the scenarios modelled, despite taxation being cited as one of the main reasons Irish farmers attended nationwide Teagasc Transferring the Family Farm (TFF) clinics held in autumn 2014, this result was acquired from a survey conducted at said clinics. This indicates that taxes may be perceived as a large financial risk for farmers when transferring land. Further research and more in-depth analysis is required to fully assess the impact of these taxes.

\section{Suitability of capital tax reliefs}

In all average scenarios (for both cattle rearing and dairy) that have been modelled, capital taxes do not apply where the successor is a son/daughter of the farmer. The thresholds for tax reliefs, although they have reduced over time, remain relatively high. Such reliefs in cases where the successor is not a son/daughter of the farmer are much lower, modelling scenarios in which the successor is a niece/nephew or non-blood relation will provide more insight into capital tax reliefs and how they impact different categories of farmers/successors. Given the high number of farmers indicating they have no successor (48\%) in Bogue's (2013) report reliefs for this category may become more pertinent; as a lack of successor may indicate that some farmers who have no successor may have no children. In these instances transfers would be to other relatives (except those who come under favourite niece/nephew - see table 1) or non-relatives in which 
cases there would be much higher capital taxes accrued. Nonetheless, the results indicate that the most common form of farm transfer (parent to child) does not result in capital taxation for average dairy and cattle rearing farms. Despite the high number of farmers attending Teagasc TFF clinics for farm transfer tax information, it would appear that only those with above average farm sizes and asset values would experience capital taxation. The high level of concern amongst farmers regarding capital taxation may be a result of societal influence. Negative experiences of farm transfer in which farmers incurred large tax bills may be sensationalised by the media and also within the social networks of some farmers, resulting in the risk of taxation unduly being of great concern to farmers. Continued dissemination of such relevant information on farm transfers by Teagasc using forums such as the TFF clinics will ensure that the farming community are aware of the factors and issues affecting farm transfer and so are more prepared for succession and inheritance.

\section{Policy incentives for farm exit}

It is evident from the results that farmers in the scenarios presented are not incentivised by any policy measures to transfer the farm early (i.e. before death). The promise of a steady income past retirement age could in fact encourage farmers to retain farm ownership. With lack of retirement income being mentioned by Riley (2014) as one of many reasons farmers are highly averse to retirement, it is expected that a high number of farmers may opt to defer farm transfer until death. Cases such as this may be contributing to the increasing number of farmers over the age of 65 in Europe (Zagata and Sutherland, 2015). Thus negatively affecting the entrance of young farmers into the sector which has been alluded to as essential for the development of agriculture (Williams, 2006). As such, if there is to be an increase in the number of young farmers in Europe, then there is a requirement to address the exit of older farmers so as to cater for the concerns and needs of both groups. Based on the tables illustrating the income streams of farmers it is apparent that there is a clear lack of policy facilitating farmer exit. As outlined previously, farmers respond positively to economic incentive (Brouwer, 2004; Sutherland, 2010) indicating that a policy of this nature may have a strong effect on the number of farmers exiting farming at retirement age. As mentioned heretofore the effects of EFRSs have been described by academics as of poor institutional value (Hennessy, 2014; Davis et al., 2013). Therefore the reintroduction of 
an EFRS may not be a suitable solution to this issue; however it is apparent that current tax reliefs may not be ample to encourage older farmers to transfer land or to participate in a phased farm management transfer approach. The fact that farmers are not encouraged by a clear policy to retire or transfer land /management earlier indicate that the policies in question may have been created at higher levels of the EU as discussed by Keating and Laffan (1999). Additionally, the notion that policies will not be effective if they do not reflect ground level issues comes to the fore (Pieckzka and Escobar, 2012). Here, young farmer entry is encouraged by certain incentives, but older farmer exit has received very little attention.

\section{Farm income: effects on succession and inheritance}

In scenarios $1 \mathrm{~A}, 1 \mathrm{~B}$ and $2 \mathrm{~A}$ the farmer retains a steady income until death, in some cases farmer income even increases. Scenario 2B contrasts somewhat to the other three presented in that the farmer's income decreases before death. This is a result of the farmer destocking from the average dairy stocking rate $(1.8 \mathrm{LU} / \mathrm{ha})$ which is higher than the average cattle rearing stocking rate (1.06 LU/ha). While a dairy system would have a reduced income as a result of destocking the farmer would benefit from decreased labour requirements. Reducing stocking rate is indicative of older farmer's management behaviour with this phenomenon being highlighted by Kristensen et al. (2004). In a case such as this, the farm is capable of producing enough income for both the farmer and their successor should they take over control of the farm. Entering a period of semiretirement could be a viable option for farmers on farms with higher incomes. Researchers have found that some farmers planned to enter a stage of semi-retirement at the age of 65 , in which the farmers would have a reduced role in managerial control and provide some labour input (Barclay et al., 2007; Kirkpatrick, 2012). Where this is an option a farmer may be able to transfer some level of farm management responsibility to their successors. However, it is also clear, given the average income figures for a cattle rearing farm that incomes are not high enough to support two generations simultaneously. Therefore, an inability of a farm to provide for exiting and entering generations has been cited as having an influence on the timing of farm transfer (Kirkpatrick, 2012), which can often be an issue for lower income farm systems. Therefore, there is merit to the notion that the level of income can be a contributing factor to a lack of business planning amongst those on more marginal farms (Tanewski 
et al., 2000) and indeed where a farm not considered a viable business there may be a tendency to perceive planning as unnecessary. Nonetheless, the evidence presented within this study suggests that an average dairy farm may be able to facilitate two generations in terms of income. A development of policy to cater for the range of farm systems and income levels would be a positive step towards increasing the number of young farmers in the sector. However the other instrumental factors associated with transfer of farm management/ownership must be considered in tandem with the economic concerns.

\section{Young farmer definitions}

One issue which has been lobbied against in Ireland is the variance in definitions of a 'young farmer' under different policies. In terms of BFP applications, a young farmer is 40 years of age or younger, while in terms of capital tax relief a young farmer is 35 years of age or younger (DAFM, 2009; Zagata and Sutherland, 2015). Given the rising average age of farmers, the cut off age to be defined as a young farmer may need to be higher to reflect the increasing age trend. Recent statistics show that at present, $10 \%$ of farmers in Ireland are aged 40 or under, with $7 \%$ of all farmers being under 35 years of age (NFS, 2013). This data implies that only $7 \%$ of farmers would be able to receive relief on capital taxes (provided they also have agricultural education) and young farmer top ups. However, those between 35 and 40 (3\%) would only qualify for a $25 \%$ top up on their BFP; disparity such as this can cause confusion amongst the farming community and should be avoided.

\section{Direct payment dependence - policy lessons}

The research undertaken has revealed that a dependence on farm payments as a source of income into retirement years is a feasible option for older farmers. In scenario 1A, a cattle farmer could destock their land to the minimum level $(0.15 \mathrm{LU} / \mathrm{ha})$ to retain LFA payment and BFP, while also receiving a state pension. In this case, the farmer benefits more financially if they do not transfer the farm until after death. The effect of this delay in inheriting passes to the successor as they do not inherit the farm until the farmer is deceased. As a result, the successor may not have worked on the farm and may thus lack the managerial experience required to maximise farm income. It may be assumed in cases such as this that successors have acquired employment outside of 
agriculture and therefore have very little experience of farm management. Gasson and Errington (1993) discuss 'ideal' types of intergenerational succession. One of these is entitled 'standby holding'. This involves a successor taking on his or her own farm until their parents are ready to transfer the family farm, allowing the successor to gain managerial experience prior to taking over, thus preparing them for the management of the family farm once they acquire it. File and Prince (1996) document evidence of the correlation between family business failure and lack of succession planning, yet also report that successors in family businesses were self-reportedly unprepared for takeover, particularly where there was no succession plan in place. For Weston (1977) the issue of management in succession is crucial to the continued success of the farm, and needed to be addressed from the earliest possible stage due to its potential to disrupt relationships between farmer and successor, and to ensure that both parties had a clear understanding of how the division of management responsibility would be handled. Avoiding 'sudden, unplanned and significant change' is cited as essential (Weston, 1977, p.243). Hutson (1987) likewise details the nature of successor preparation for management as a sustained and complex one, especially on family farms where not only are there likely to be ideological and educational differences between farmer and successor, but where the wider context for farming is also under a state of constant change. Hutson (1987) also notes that successors in some small businesses have to compromise their ambitions for the family business until they gain managerial control, but that there was the risk that said ambitions may have faded by the time transfer takes place. As a potential way to address concerns regarding successor preparation, Errington (2002) discusses the idea of a 'professional detour'. This is a period in which a young farmer acquires education or work experience not specifically related to agriculture. The successor may acquire skills that are transferable to farm management during their time away from the family farm. Weston (1977) likewise argues that training in areas such as business management may be just as beneficial as agricultural training to a young farmer.

Successors may be averse to expansion or investment as they would most likely have gone past their late 30s by the time they inherit the family farm (Figures 1 and 2 presented earlier illustrate the decrease in farm income after late 30's, indicating a lack of investment/expansion after this age). Wilkinson (2012) alludes to a similar issue 
noting that successors may not be willing to invest the required time or money needed to rejuvenate a farm once the retirement effect has taken place.

The fact that farmers may acquire payments while also receiving a pension indicates that there may have been an oversight from policy makers. Based on the stages of policy formulation discussed by Greer (2005) it may be the assessment stage that is being neglected. As mentioned, this is the stage of policy formulation in which previous policies are reviewed. In the case of CAP payments policy makers seem to have failed to notice this issue which continues to be a factor influencing intergenerational land mobility. The creation of a policy that does not allow farmers to retain farm payments when they acquire a pension may increase incidence of land transfer. However this may generate issues of retirement income for farmers, therefore the resultant issue of retirement income would need to be addressed.

\section{Conclusion}

The above discussion has sought to provide some explanation to the seemingly intractable problem of an ageing farmer profile coupled with a reluctance to engage in farm transfer, using Ireland as a case study example. The extent to which this could be connected with a set of risk factors linked to current fiscal measures underpinning succession and inheritance was investigated. This yielded a range of potential outcomes, indicating that the process is complex and specific to individual holdings and their particular structure and composition. Each route to succession and inheritance that has been discussed will have a different economic impact on the current and future income of all parties involved in farm transfer. The various means by which individuals undertake succession/inheritance is justifiable as there are a range of income levels, asset values, personal reasons and farm systems, meaning there is no single 'optimal' route to be taken. This variance in routes to farm succession and inheritance needs to be reflected in agricultural policy in order to facilitate the development of a sector that is efficient and sustainable (i.e. one which contains a significant cohort of young farmers). In the absence of a strong policy incentive, the average age of farmers may continue to rise resulting in a stagnant land market and indeed an agricultural sector that does not meet contemporary demands. 


\section{Future research}

One issue which has not yet been addressed in the modelling above is the cost of long term care and the effects of the Fair Deal Scheme ${ }^{3}$. This can result in an on-going expense for retired farmers or in some cases may be paid for by their successors. The cost of long term care can often be high adding to financial concerns around succession and inheritance i.e. if a farmer transfers the farm, will they be capable of paying this cost. Behavioural analysis of farmers around the time succession and inheritance takes place will also need to be undertaken to assist with understanding the actors and drivers most influencing the decision to transfer.

\footnotetext{
${ }^{3}$ *The Fair Deal Scheme (Also known as the Nursing Home Support Scheme, is a scheme of financial support for people who need long-term nursing home care. Those who require care may apply for the scheme which will contribute to nursing home costs, along with a contribution from the applicant which is calculated based on income and personal assets. Those in receipt of the payment may defer their personal contribution until death, meaning a next of kin would pay the balance.
} 


\section{References}

ADAS Consulting Ltd., 2004. 'Entry to and Exit from Farming in the United Kingdom', Prepared for The Department of Environment, Food and Rural Affairs.

Bacidore, J., Boquist, J., Milbourn, T., and Thakor, J., 1997. 'The search for the best financial performance measure', Financial Analysts Journal, 53 (3), pp. 11 -20.

Barclay, E., Foskey, R., and Reeve, I., 2007. 'Farm Succession and Inheritance Comparing Australian and International Trends', A report for the Rural Industries Research and Development Corporation, RIRDC Publication No. 07/066.

Bogue, P., 2013. 'Land Mobility and Succession in Ireland', report prepared for Macra na Feirme.

Brandth, B., and Overrein, G. 2013. 'Resourcing Children in a Changing Rural Context: Fathering and Farm Succession in Two Generations of Farmers', Sociologia Ruralis, 53 (1), pp. $95-111$.

Briassoulis, H., 2008. Land-use policy and planning, theorizing, and modeling: lost in translation, found in complexity?. Environment and Planning B: Planning and Design, 35(1), pp.16-33.

Brouwer, F. ed., 2004. Sustaining Agriculture and the Rural Environment: Governance, Policy, and Multifunctionality. Edward Elgar publishing.

Calus, M., Van Huylenbroeck., and Van Lierde, D., 2008. 'European Society for Rural Sociology', Sociologia Ruralis, 48 (1), pp. 38 - 56.

Caskie, P., Davis, J., Campbell, D. and Wallace, M., 2002. An economic study of farmer early retirement and new entrant schemes for Northern Ireland. Queen's University Belfast.

Centre for Integrated Agricultural Systems (CIAS), 1996. New Zealand's dairy career path: evaluating a farm entry/exit strategy', Research Brief \#34, http://www.cias.wisc.edu/sharemilking-in-wisconsin-evaluating-a-farm-entryexitstrategy/, (27/03/15). 
Conway, S, F, McDonagh, J., Farrell, M., and Kinsella, A. 2016. 'Cease agricultural activity forever? Understanding the importance of symbolic capital', Journal of Rural Studies, 44, pp. $164-176$.

Curran, T., 2014. 'Dairy Share Farming', Teagasc Collaborative Farming Conference 2014, Clonmel Park Hotel, 17 ${ }^{\text {th }}$ April 2014, Teagasc: Athenry, Available at: http://www.teagasc.ie/publications/2014/3155/index.asp, Accessed 16/12/15.

Davis, J., Caskie, P. and Wallace, M., 2009. Economics of farmer early retirement policy. Applied Economics, 41(1), pp.35-43.

Department of Agriculture, Food and the Marine., 2009. 'Value for money review: The young farmers installation scheme', May 2009.

File, K.M. and Prince, R.A., 1996. Attributions for family business failure: The heir's perspective. Family Business Review, 9 (2), pp.171-184.

Fischer, H. and Burton, R.J., 2014. 'Understanding farm succession as socially constructed endogenous cycles'. Sociologia ruralis, 54, (4), pp.417-438.

Food Harvest 2020: A vision for Irish agri-food and fisheries., 2010. Department of Agriculture Fisheries and Food, Ireland.

Greer, A., 2005. Agricultural policy in Europe. Manchester University Press.

Groom, B., Koundouri, P., Nauges, C., and Thomas, A., 2008. 'The story of the moment: risk averse Cypriot farmers respond to drought management', Applied Economics, 40 (3), pp. 315 - 326.

Gullifer, J., and Thompson, A, P., 2006. 'Subjective realities of older male farmers: Self-perceptions of ageing and work', Rural Society, 16 (1), pp. 80 - 97.

Hanrahan, K., Hennessy, T., Kinsella, A., and Moran, B., 2013. National Farm Survey 2013, Rural Economy and Development Programme, Athenry, Galway.

Heanue, K., and O’Donoghue, C., 2014. 'The Economic Returns to Formal Agricultural Education', Teagasc Rural Economy and Development Programme: Athenry. 
Hennessy, T. (2014) 'CAP 2014-2020 tools to enhance family farming: opportunities and limits', prepared for the European Parliament's Committee on Agriculture and Rural Development.

Hennessy, T., and Rehman, T., 2007. 'An Investigation into Factors Affecting the Occupational Choices of Nominated Farm Heirs in Ireland', Journal of Agricultural Economics, 58 (1), pp. $61-75$.

Hill, B., 2000. Farm incomes, wealth and agricultural policy (No. Ed. 3). Ashgate Publishing Ltd.

Hooghe, L. and Keating, M., 1994. The politics of European Union regional policy. Journal of European Public Policy, 1(3), pp.367-393.

Howley, P., O'Donoghue, C., and Heanue, K., 2012. 'Factors Affecting Farmers' Adoption of Agricultural Innovations: A Panel Data Analysis of the Use of Artificial Insemination among Dairy Farmers in Ireland', Journal of Agricultural Science, 4 (6), pp. $171-179$.

Hutson, J., 1987. Fathers and sons: family farms, family businesses and the farming industry. Sociology, 21 (2), pp.215-229.

Ingram,J., and Kirwan, J., 2011. 'Matching new entrants and retiring farmers through joint ventures: Insights from the Fresh Start Initiative in Cornwall, UK', Land Use Policy, 28, pp. $917-927$.

Inwood, S, M., and Sharp, J, S., 2012. 'Farm persistence and adaptation at the rural urban interface: Succession and farm adjustment', 28, pp. $101-117$.

Jechlitschka, K., Kirschke, D., and Schwarz, G., 2007. 'Microeconomics using Excel: Integrating economic theory, policy analysis and spreadsheet modelling', Routledge, Oxon.

Kelly, P, W., 1982. 'Agricultural Land - Tenure and Transfer', Socio-economic research series, Economics and Rural Welfare Research Centre.

Kirkpatrick, J., 2012. 'Retired Farmer - An Elusive Concept', in Baker, M. J., Whitehead, I., and Lobley, M. (Eds.) (2012) 'Keeping it in the family: international 
perspectives on succession and retirement on family farms', Ashgate Publishing, Ltd: Surrey.

Koundouri, P., Laukkanen, M., Myyra, S., and Nauges, C., 2009. 'The effects of EU agricultural policy changes on farmers' risk attitudes', European Review of Agricultural Economics, pp. $1-25$.

Kristensen, L, S., Thenail, C., and Kristensen, S, P., 2004. 'Landscape changes in the 1990s: the interaction between farmers and the farmed landscape. A case study from Jutland, Denmark', Journal of Environmental Management, 71, pp. 231 - 244.

Lapple, D., and Hennessy, T., 2012. 'The capacity to expand milk production in Ireland following the removal of milk quotas', Irish Journal of Agricultural Food Research, 51, pp. $1-11$.

Leach, P, C. 2016. 'Succession Planning in Family Businesses: Consulting and Academic Perspectives', in Baker, J., 2016. Keeping it in the family: international perspectives on succession and retirement on family farms. Routledge, pp. $193-211$.

Lobley, M., Baker, J, R., and Whitehead, I., 2010. 'Farm succession and retirement: Some international comparisons', Journal of Agriculture, Food Systems, and Community Development, 1 (1), pp. $49-64$.

Loughrey, J., Thorne, F., Kinsella, A., Hennessy, T., O’Donoghue, C., and Vollenweider, X., 2015. 'Market risk management and the demand for forward contracts among Irish dairy farmers', International Journal of Agricultural Management, $00(00)$, pp. $1-8$.

Matthews, A., 2014. 'The Agri-Food Sector', in O'Hagan, J., and Newman, C. (eds.) (2014) 'The Economy of Ireland: National and Sectoral Policy Issues', $12^{\text {th }}$ Edition, Gill and Macmillan: Dublin.

McDonnell, J., 2014. 'Management Data for Farm Planning 2013/2014', Teagasc.

Mills - Novoa, M., 2011. 'Sustaining Family Farming Through Mentoring: A Toolkit for National Family Farm Coalition Members', National Family Farm Coalition, USA. 
Mitton, L., Sutherland, H., and Weeks, M. (Eds.)., 2000. 'Microsimulation modelling for policy analysis: challenges and innovations', (No. 65). Cambridge University Press.

Morris, C., and Potter., C., 1995. 'Recruiting the new conservationists: farmers' adoption of agri-environmental schemes in the UK', Journal of Rural Studies, 11 (1), pp. 51-63.

Norton, R.D., 2004. Agricultural development policy: Concepts and experiences. John Wiley \& Sons.

O'Donoghue, C., 2014. 'Handbook of Microsimulation Modelling', (Contributions to Economic Analysis, Volume 293) Emerald Group Publishing Limited.

OECD, https://data.oecd.org/pension/net-pension-replacement-rates.htm\#indicatorchart, accessed 1/04/15.

Potter, C., and Lobley, M., 1996. 'Unbroken Threads? Succession and its Effects on Family Farms in Britain', Sociologia Ruralis, 36 (3), pp. 286 - 306.

Riley, M., 2014. 'Still being the 'Good Farmer' (Non-retirement) and the Preservation of Farming Identities in Older Age', Sociologia Ruralis, pp. 1 - 20.

Shawyer, A., 1990. Farm structure and farm families: a Nottinghamshire field area. East Midland Geographer 13, 1-18.

Spadaro, A. (Ed.)., 2007. 'Microsimulation as a tool for the evaluation of public policies: methods and applications', Fundacion BBVA.

Sutherland, L.A., 2010. Environmental grants and regulations in strategic farm business decision-making: a case study of attitudinal behaviour in Scotland. Land Use Policy, 27(2), pp.415-423.

Tanewski, G.A., Romano, C.A. and Smyrnios, K.X., 2000. Determinants of Australian family farm growth. Rural Ind Res and Dev Corp, Barton.

Taylor, J, E., Norris, E, N., and Howard, W., 1998. Succession Patterns of Farmer and Successor in Canadian Farm Families', Rural Sociology, 63 (4), pp. 553 - 573. 
Terres, J.M., Scacchiafichi, L.N., Wania, A., Ambar, M., Anguiano, E., Buckwell, A., Coppola, A., Gocht, A., Källström, H.N., Pointereau, P. and Strijker, D., 2015. Farmland abandonment in Europe: Identification of drivers and indicators, and development of a composite indicator of risk. Land Use Policy, 49, pp.20-34.

Turley, G., and Maloney, M., 1997. 'Principles of Economics: An Irish Textbook', Gill and Macmillan: Dublin.

Vanclay, F., 2004. 'Social principles for agricultural extension to assist in the promotion of natural resource management', Australian Journal of Experimental Agriculture, 44, pp. $213-222$.

Weston, W. ,1977. The problem of succession, Farm Management 3, 237-246.

Williams, F., 2006. 'Barriers Facing New Entrants to Farming - an Emphasis on Policy', Land Economy Working Paper Series, Land Economy Research Group, SAC, Aberdeen.

Wilkinson, R. 2016. 'New Patterns of Succession in the Australian Wool Industry', in Baker, J., 2016. Keeping it in the family: international perspectives on succession and retirement on family farms. Routledge, pp. $37-53$.

Zagata, L., and Sutherland, L., 2015. 'Deconstructing the 'young farmer problem in Europe': Towards a research agenda', Journal of Rural Studies', 38, pp. 39 - 51. 